\title{
Między humanizmem a technicyzmem. Spór o model nauczania prawa w polskim dyskursie prawniczym
}

Sposób nauczania prawa to jeden z najbardziej dyskusyjnych problemów, jaki stale jest obecny i aktualny w dyskursie prawniczym nie tylko w Polsce, ale $\mathrm{w}$ zasadzie na całym świecie. $\mathrm{W}$ trakcie debaty ścierają się rozmaite wizje edukowania przyszłych prawników stosownie do ich przyszłej społecznej roli. Dyskusja ta niejednokrotnie przebiera postać sporu „starzy” - „młodzi” czy „teoretycy” - „praktycy”, gdzie ci pierwsi zazwyczaj bronią dotychczasowego modelu nauczania, natomiast ci drudzy uzasadniają konieczność jego zmiany potrzebą dostosowania nauczania do aktualnych zmian i trendów społecznych. Celem niniejszego opracowania jest ukazanie, iż osią sporu nad kształtem edukacji prawniczej, jaki od dawna toczy się w Polsce, jest debata pomiędzy humanistyczną a technicystyczną perspektywą postrzegania roli nauki uniwersyteckiej ${ }^{1}$. Przyjęcie jednej z wymienionych perspektyw powoduje konsekwencje wynikające $\mathrm{z}$ takiego postrzegania - czyli określenie roli prawnika w relacjach społecznych $^{2}$, co z kolei wpływa na sposób jego kształcenia. Omówienie kształtu edukacji prawniczej w zależności od przyjętej perspektywy wymaga skrótowego nakreślenia, jak należy rozumieć każdą ze wspomnianych perspektyw.

Perspektywa humanistyczna stanowi odwołanie do formującej się już od okresu starożytności idei humanizmu ${ }^{3}$ Nie ma tu miejsca na szerokie omówienie fluktuacji znaczenia pojęcia „humanizm”. W tym miejscu wystarczy odwołać się do podstawowych założeń tej idei. Najogólniej rzecz ujmując, opiera się ona na założeniu antropocentryzmu i szeroko rozumianego dążenia do rozwoju

1 J. Wróblewski, Prawoznawstwo: Perspektywa technicystyczna i humanistyczna. Z problemów III Kongresu Nauki, „Państwo i Prawo” 1986, z. 5, s. 4-5.

2 Zob. A. Szwarc, Problemy kształcenia prawniczego, „Państwo i Prawo” 2010, z. 1, s. 3-4.

3 Aczkolwiek samo pojęcie „humanizm” pojawia się dopiero w 1808 r., użyte przez niemieckiego pedagoga F. J. Niethammera, w książce Der Streit des Philanthropismus und des Humanismus in der Theorie des Erziehungsunterrichts unserer Zeit. T. Baldwin, The humanism debate, [w:] B. Leiter, M. Rosen (eds), The Oxford Handbook of Continental Philosophy, Oxford 2007, s. $671-672$. 
osobowości człowieka4 $\mathrm{W}$ ujęciu humanistycznym nauka jest traktowana jako szeroko pojmowany element kultury, a w trakcie nauczania najważniejsze jest kształtowanie charakteru człowieka i wpojenie mu poczucia pewnego rodzaju misji społecznej. Humanista, mający wszechstronne spojrzenie na rzeczywistość społeczną, ma niezwykle istotną rolę do spełnienia: ma obowiązek oddziaływać wychowawczo na społeczeństwo oraz kształtować umysły innych ludzi ${ }^{5}$. Wykonywanie tych zadań nie przynosi od razu wymiernych rezultatów, lecz obliczone jest na twórcze oddziaływanie na społeczeństwo ${ }^{6}$. Działania humanisty nie będą nigdy bezpośrednio przeliczalne na konkretne efekty społeczne - takie zresztą też ze swej natury być nie mogą. Ich skutki mogą się ujawnić dopiero po wielu latach, a czasem nawet w ogóle. W tym sensie ujęcie humanistyczne kładzie nacisk na bardziej projakościowe oddziaływanie na osobowość człowieka, które ostatecznie może nie przynieść żadnych efektów.

Odmienne założenia przyjmuje technicystyczne ujęcie nauki i nauczania. W tym ujęciu nauka, a w konsekwencji także nauczanie, ma prowadzić do uzyskania wymiernych efektów, przynoszących społeczeństwu konkretne profity ${ }^{7}$. Jak pisał Jerzy Wróblewski, model nauki w tej perspektywie składa się z trzech następujących po sobie poziomów ${ }^{8}$. Na pierwszym ustala się obiektywne prawdy o charakterze naukowym - ujawniają się one w trakcie badań, a następnie są opisywane. W drugim etapie na podstawie tych konkretnych wyników badań tworzone są pewne normy techniczne postępowania, które mają charakter próby przeniesienia wyników badań do rzeczywistości społecznej. Natomiast trzeci etap sprowadza się do praktycznego stosowania tych norm technicznych, opartych na wcześniejszych odkryciach naukowych ${ }^{9}$.

Funkcjonowanie tego ujęcia nauki uzależnione jest od uzyskiwania określonych efektów, które bez trudu można zastosować w rzeczywistości społecznej. Nauka w tym aspekcie pełni funkcję instrumentalną wobec potrzeb społecznych, a wyniki badań powinny przynosić pewien społecznie wymierny efek $\mathrm{t}^{10}$.

4 J. P. van Praag, The Foundations of Humanism, New York 1982 - fragmenty w tłumaczeniu Ł. Nyslera publikowane są w serwisie: www.humanizm.free.ngo.pl. Zob. też: A. Borowski, Humanizm jako przedmiot wspótczesnej humanistyki, [w:] idem (red.), Humanizm. Historie pojęcia, Warszawa 2009.

$5 \mathrm{~W}$. Veugelers, A humanist perspective on moral development and citizenship education, [w:] idem (ed.), Education and Humanism. Linking Autonomy and Humanity, Rotterdam 2011, s. 9 i n.

6 Zob. B. Łapicki, O humanistycznym wychowaniu prawnika, „Państwo i Prawo” 1948, Z. 5-6, s. 95.

7 E. Schuurman, Philosophical and ethical problems of technicism and genetic engineering, „Society for Philosophy and Technology” 1997, vol. 3, nr 1; http://scholar.lib.vt.edu/ejournals/SPT/ v3n1/schuurman.html (dostęp: 29.05.2013).

8 J. Wróblewski, op. cit., s. 4-5.

9 Ibidem.

${ }^{10}$ D. Carr, Making Sense of Education: An Introduction to the Philosophy and Theory of Education and Teaching, New York 2003, s. 220. 
Zdobywana wiedza ma więc dostarczać gotowych technicznych rozwiązań, umożliwiających realizację zamierzonych celów społecznych, np. podnoszenie jakości życia, wprowadzanie rozwiązań technicznych ułatwiających życie itp. ${ }^{11}$ Technicystyczne ujęcie nauki zakłada odejście od prowadzenia badań, które mają charakter „teoretyzowania”, czyli nie przynoszą wyników mogących znaleźć zastosowanie w rzeczywistości społecznej, a więc nie dają praktycznych rozwiązań dla pojawiających się problemów.

$\mathrm{Na}$ tle tych dwóch ujęć nauki pojawia się pytanie, w jakim miejscu powinno się znaleźć prawoznawstwo. Czy ma ono bardziej charakter nauki dostarczającej społeczeństwu gotowych rozwiązań - czyli, inaczej mówiąc, ma wymiar praktyczny? Czy też nauka prawa powinna być postrzegana jednak z perspektywy humanistycznej? Nie jest celem niniejszego opracowania udzielenie odpowiedzi na tak postawione pytanie - wszak można mieć wątpliwości, czy w ogóle jest możliwa jednoznaczna odpowiedź, biorąc pod uwagę wielowymiarowość rozumienia prawa. Celem tego tekstu jest ukazanie, iż od samego początku dyskursu dotyczącego edukacji prawniczej podstawowym pytaniem w zasadzie jest to, jak należy postrzegać rolę prawnika w społeczeństwie - i od odpowiedzi na to pytanie zależy określenie modelu edukacji prawniczej, jaki należy przyjać. Dyskusja nad charakterem studiów prawniczych dotyczy więc w swej istocie szerszego problemu miejsca i roli prawnika w społeczeństwie. Ścieraja się w niej często skrajnie odmienne stanowiska i z tego powodu czasami bywa bardzo zażarta. Współcześnie problem humanistycznego lub technicystycznego postrzegania wykonywania zawodu prawniczego szczególnie ożywa przy polemice dotyczącej otwierania zawodów prawniczych, globalizacji na rynku usług prawniczych, czy wreszcie powstawania bardzo szczegółowych regulacji prawnych w wielu dziedzinach życia. Pojawia się pytanie: w jaki sposób kształcić prawników, aby byli w stanie sprostać zadaniom stawianym przed nimi przez współczesne realia życia społecznego?

W Polsce debata dotycząca wskazanego problemu rozpoczęła się wraz z odzyskaniem niepodległości w roku 1918 i z większymi lub mniejszymi przerwami toczy się do dnia dzisiejszego ${ }^{12}$. W trakcie tej debaty w zasadzie padają te same argumenty, z pewnymi tylko nieznacznymi modyfikacjami, uzależnionymi od aktualnych tendencji społecznych. Najwięcej głosów polemicznych dotyczących humanistycznego lub praktycznego charakteru studiów prawniczych pojawiło się w okresie dwudziestolecia międzywojennego, w dwóch wielkich debatach. Pierwsza z nich toczyła się w latach 1919-1923 głównie

${ }^{11}$ Szerzej o perspektywie technicystycznej w nauce zob. E. Shuurman, Technology and the Future. A Philosophical Challenge, Toronto 1980; idem, Faith and Hope in Technology, Toronto 2003.

${ }^{12}$ Dyskusję i zmiany w modelu studiów w okresie PRL przedstawia W. Rozwadowski, Reformy studiów prawniczych, „Edukacja Prawnicza” 1994, nr 1, s. 1-5. 
pomiędzy dwoma profesorami Uniwersytetu Jana Kazimierza we Lwowie: historykiem Oswaldem Balzerem i karnistą Juliuszem Makarewiczem ${ }^{13}$. Z kolei druga, przypadająca na lata 1931-1937, miała zdecydowanie szerszy zasięg, gdyż uczestniczyły w niej wszystkie środowiska zainteresowane sposobem kształcenia prawników: od środowisk akademickich, poprzez koła rządowe, aż po praktyków stosujących prawo ${ }^{14}$. W debatach nad sposobem nauczania prawa w okresie PRL oraz po 1989 r. również pojawiały się wątki odnoszące się do perspektywy humanistycznej bądź technicystycznej, lecz właściwie powtarzały one argumenty, jakie padły w dyskusji przypadającej na lata II RP. Z tego względu przedmiotem analizy będą przede wszystkim argumenty podnoszone w tamtym okresie, co jak się okaże, wcale nie spowodowało, iż straciły one na swej aktualności ${ }^{15}$.

Spór o charakter nauczania prawa, jaki można dostrzec w Polsce od lat 20. ubiegłego stulecia, jest w zasadzie pochodną sporu o to, w jaki sposób powinno być rozumiane, a w konsekwencji nauczane prawo. Debaty na ten temat toczyły się w różnych państwach w Europie i w Stanach Zjednoczonych, począwszy od drugiej połowy XIX w. ${ }^{16}$ Miały one swe źródło w szybkich przemianach

${ }^{13}$ Dyskusja ta zamknęła się w kilku opublikowanych artykułach i wzajemnych replikach. Zob. O. Balzer, $W$ sprawie reformy nauki prawa $w$ uniwersytetach polskich, „Przegląd Prawa i Administracji” 1919; idem, Nauka uniwersytecka a kolejność studiów w uniwersyteckiej nauce prawa, Warszawa 1921; idem, Glosy do artykułu o kolejności studiów prawa, „Przegląd Prawa i Administracji” 1922; idem, Dwa światy, „Czasopismo Prawnicze i Ekonomiczne” 1923, nr 10-12; J. Makarewicz, Reforma metody nauczania prawa, „Przegląd Prawa i Administracji” 1919; idem, Kolejność studiów prawniczych, „Przegląd Prawa i Administracji” 1921; idem, Dwa światopoglady, „Ruch Prawniczy i Ekonomiczny” 1922. Samą polemikę szczegółowo opisuje G. Kowalski, O miejsce historii prawa w programie studiów uniwersyteckich. Polemika między Oswaldem Balzerem a Juliuszem Makarewiczem (1919-1923), „Czasopismo Prawno-Historyczne” 2004, t. LVI, z. 2 oraz M. Marszał, J. Srokosz, Oswalda Balzera z Juliuszem Makarewiczem polemika o charakter studiów prawniczych [w:] Актуальні проблеми історії держсави і права країн Центрально-Східної Європи (присвячена 150-річчю Освальда Бальчера). Матеріали міжнародної наукової конференції 24-25 квітня 2009 р., Львів 2009.

${ }^{14}$ Zob. szerzej M. Marszał, J. Srokosz, Rzymianie czy barbarzyńcy? Z dyskusji nad reforma programu studiów prawniczych w Polsce w latach 1931-1937, „Przegląd Prawa i Administracji” 2010, t. LXXXIII, s. 263-287.

${ }^{15}$ Zob. A. Turska (red.), Humanizacja zawodów prawniczych a nauczanie akademickie, Warszawa 2002.

${ }^{16} \mathrm{~W}$ Stanach Zjednoczonych, pomimo podejmowanych tam w XIX w. prób przeszczepu europejskiego, ogólnokształcącego i humanistycznego modelu nauczania prawa, m.in. przez Thomasa Jeffersona, ukształtował się zupełnie inny sposób edukacji. System ten miał na celu przygotowanie przede wszystkim praktyków, stąd też jego podstawowym celem było nauczanie pewnych konkretnych umiejętności, zwłaszcza, iż po zakończeniu studiów uniwersyteckich nie przewidywano okresu aplikacji. Zob. R. Stevens, Law School. Legal Education in America from the 1850s to the 1980s, Chapel Hill-London, s. 637 i n. Zob. też Ch. McManis, The history of first century American legal education. A revisionist perspective, „Washington University Law Quartely" 1891-1892, nr 59. 
społecznych na przełomie XIX i XX w., wynikających z gwałtownego postępu naukowego i technicznego oraz znacznych przekształceń struktury społecznej. Okres ten to także czas znacznych zmian w prawoznawstwie - dominacji pozytywizmu prawniczego i pojawiania się wielkich kodyfikacji, a także regulowania nowych dziedzin życia społecznego. W tym okresie rozrastały się zupełnie nowe dziedziny prawa, czasami bardzo szczegółowo unormowane. Wszystkie te zjawiska zmuszały do postawienia pytania o to, czy dotychczasowy model nauczania odpowiada potrzebom rzeczywistości społecznej.

Przypomnijmy, że uniwersyteckie nauczanie prawa na początku XX w. w Europie miało głównie charakter nauczania humanistycznego. Prawnik był postrzegany nie tylko jako fachowiec mający pomagać w rozstrzyganiu sytuacji konfliktowych, lecz bardziej jako osoba mająca wychowawczo oddziaływać na społeczeństwo. Poza wypełnianiem obowiązków zawodowych wymagano od niego także pewnego społecznego zaangażowania - wykonywanie zawodu prawniczego było swoistym rodzajem misji społecznej. Studia prawnicze na uniwersytetach były oparte przede wszystkim na przedmiotach teoretycznych, dostarczających wiedzy ogólnej, a w mniejszym stopniu nauczających konkretnych przepisów prawa ${ }^{17}$.

Pod wpływem wspomnianych wcześniej zmian w życiu społecznym i komplikowania się relacji międzyludzkich, początkowo nieśmiało, lecz z czasem coraz silniej, pojawiały się wizje prawnika mającego być nie ogólnie wykształconym humanistą, lecz profesjonalnym specjalistą w konkretnej dziedzinie, którego praca i jej efekty podobne były do pracy inżyniera czy lekarza. Zwolennicy tego nurtu wskazywali, iż dotychczasowy model kształcenia nie zdawał egzaminu w nowej rzeczywistości społecznej, dlatego też humanistyczne, ogólnorozwojowe studia prawnicze powinny zostać zastąpione modelem studiów zorientowanych na praktyczne kształcenie specjalistów, zbliżone do sposobu kształcenia na politechnikach ${ }^{18}$.

${ }^{17}$ Szerzej o programach nauczania prawa w okresie II RP zob. K. Krasowski, Wydziat Prawno-Ekonomiczny Uniwersytetu Poznańskiego w latach 1919-1939, Poznań 2006, s. 217; G. Bartłuszajtys (red.), Zarys dziejów Wydziału Prawa i Administracji Uniwersytetu Warszawskiego 1808-2008, Warszawa 2008, s. 154-158; A. Święcicki, Wydział Prawa i Nauk Społecznych Uniwersytetu Stefana Batorego i jego spuścizna, [w:] K. Piechnik, K. Puchowski (red.), $Z$ dziejów Almae Matros Vilnensis. Księga pamiatkowa ku czci 400-lecia założenia i 75-lecia wskrzeszenia Uniwersytetu Wileńskiego, Kraków 1996, s. 94-100; E. Gumowska, Moje studia prawnicze na Uniwersytecie Stefana Batorego, [w:] K. Piechnik, K. Puchowski (red.), op. cit., s. 105-109; J. Dybiec, Uniwersytet Jagielloński 1918-1939, Kraków 1939, s. 190-203; A. Redzik, Nauczanie i nauka prawa politycznego na Uniwersytecie Jana Kazimierza we Lwowie, „Przegląd Sejmowy" 2007, nr 5, s. 111-142.

${ }^{18}$ Najdobitniej ujął to Antoni Deryng, mówiąc, że „wydział prawa winien być politechniką nauk społecznych". Głos w dyskusji prof. Derynga w: Sprawozdanie z I Zjazdu Profesorów i Docentów Prawa Publicznego odbytego $w$ dniach 6-8 kwietnia 1936 roku w Poznaniu, „Rocznik Polskiego Instytutu Prawa Publicznego" 1936-1937, t. I, s. 48. 
Wydaje się, iż najtrafniej istotę tego sporu określił Czesław Znamierowski, pisząc, że tak naprawdę jest to spór o wizję osoby prawnika: czy prawnik miał być „rzymianinem wykształconym na brykach”, czy też „uczciwie wyspecjalizowanym barbarzyńcą"? ${ }^{19} \mathrm{~W}$ pierwszym przypadku oznaczało to artystę w swoim zawodzie, z otwartym umysłem, opuszczającego uniwersytet z wiedzą ogólną; z kolei w drugim - rzemieślnika, za to doskonale znającego wybraną dziedzinę prawa. W sporze tym padały rozmaite argumenty, mające uzasadnić humanistyczny lub technicystyczny charakter roli prawnika w społeczeństwie.

W pierwszej kolejności przedstawmy racje zwolenników humanistycznego postrzegania istoty studiów prawniczych. Zwykle koronnym argumentem tego stanowiska było odwołanie się do etosu uniwersytetu i uprawianej tam nauki. Uniwersytety przedstawiane były jako najdoskonalszy typ szkół wymyślonych przez człowieka, łączący w sobie prowadzenie badań naukowych z nauczaniem ${ }^{20}$. Taki cel uniwersytetu pozostawał niezmienny od czasów średniowiecza. Przechodząc bez szwanku kolejne zmiany społeczne, dowiódł tym samym swojej ponadczasowości. Pomimo istnienia dwutorowości działania uniwersytetów, ich najważniejszym zadaniem było jednak prowadzenie badań naukowych oraz dążenie do prawdy, czyli rozszerzanie dotychczasowego stanu wiedzy ${ }^{21}$. Nauka uprawiana na uniwersytetach nie musiała mieć znaczenia praktycznego, sprowadzonego do możliwości bezpośredniego zastosowania osiąniętych efektów w rzeczywistości społecznej.

Nie należy oczywiście zapominać o edukacyjnej działalności uniwersyteckiej, bez której - jak pisał Bohdan Winiarski - byłyby one rodzajem zamkniętych towarzystw naukowych ${ }^{22}$. Musiały one bowiem w twórczy sposób łączyć prowadzenie badań naukowych $\mathrm{z}$ nauczaniem ${ }^{23}$. Tym niemniej nie można było sprowadzić roli edukacji uniwersyteckiej jedynie do praktycznego nauczania wykonywania określonego zawodu ${ }^{24}$. Rolą uniwersytetu było przede wszystkim wykształcenie elity intelektualnej, mającej wychowawczy wpływ na społeczeństwo; uniwersytet odpowiadał za ukształtowanie tej prospołecznej postawy w swoich absolwentach. $Z$ tej racji nie można go postrzegać jako miejsca, gdzie przekazuje się tylko wiedzę o obowiązującym prawie. Instytucja, która swoją działalność

${ }^{19}$ C. Znamierowski, Nil desperandum, „Gazeta Polska”, 28 kwietnia 1937, s. 1.

${ }^{20}$ B. Winiarski, Zagadnienie organizacji studiów prawniczych, „Ruch Prawniczy Ekonomiczny i Socjologiczny" 1937, nr 2, s. 133.

${ }^{21}$ O. Balzer, Nauka uniwersytecka ..., s. 5-8.

${ }^{22}$ B. Winiarski, op. cit., s. 135.

${ }^{23}$ Ibidem.

${ }^{24}$ „Zadaniem studiów jest poznawanie i roztrząsanie ogólnych zasad prawnych, a nie wkuwanie przepisów szczeblowych" - twierdził A. Peretiakowicz. Wywiad z profesorem dr. Antonim Peretiakowiczem, Rektorem Uniwersytetu Poznańskiego, „Współczesna Myśl Prawnicza” 1936, nr 11, s. 7. 
sprowadzałaby do przekazywania studentowi suchej wiedzy prawniczej, byłaby wyłącznie szkołą prawa, a jej absolwenci - rzemieślnikami prawa ${ }^{25}$, albo inaczej, prawniczymi niedoukami ${ }^{26}$.

$\mathrm{Z}$ tak rozumianej misji społecznej uniwersytetów wypływała wizja celu nauczania na wydziałach prawa, którym było ukształtowanie charakteru i sposobu myślenia studenta, zaś mniejsze znaczenie miało nauczenie znajomości przepisów obowiązującego prawa ${ }^{27}$. Chodziło głównie o wyrobienie w studencie swego rodzaju habitus intelectualis - pewnej postawy ustawicznego dążenia do samodoskonalenia, pogłębiania posiadanej wiedzy oraz pracy nad swoją osobowością ${ }^{28}$. Niemniej ważnym celem studiów prawniczych było wyrobienie w przyszłym prawniku wrażliwości na problemy społeczne i wewnętrznego przekonania o konieczności etycznego postępowania. Takiej postawy nie dało się ukształtować, jedynie ucząc przepisów obowiązującego prawa i technik ich wykonywania ${ }^{29}$. W trakcie edukacji prawniczej należało ukazać szerszy społeczny kontekst funkcjonowania konkretnych elementów porządku prawnego.

Czesław Martyniak akcentował dwoisty charakter pracy prawnika: z jednej strony zawodowo-techniczny, ograniczający się do umiejętności właściwej subsumpcji sytuacji z rzeczywistości społecznej do odpowiednich przepisów prawnych, z drugiej strony zaś aspekt społeczny, który wyrażał się w pełnieniu ról doniosłych społecznie ${ }^{30}$. Wśród tych ostatnich autor wymieniał przede wszystkim: stanie na straży ładu prawnego w państwie, kształtowanie poczucia prawnego społeczeństwa, wreszcie kształtowanie życia społecznego poprzez odpowiednie stosowanie norm prawnych ${ }^{31}$. Aby prawnik nie stał się w swej pracy podobny do automatu stosującego przepisy prawa w sposób mechaniczny, należało wykształcić w nim szerokie horyzonty myślowe i postawę prospołeczną. Prawnik opuszczający mury uniwersyteckie musiał przede wszystkim zdawać sobie sprawę z doniosłości swojej roli społecznej i odpowiedzialności płynącej z jej pełnienia. $\mathrm{Z}$ tego powodu nie mógł być traktowany jako technik społeczny, którego zadanie polega na prostym subsumowaniu sytuacji życiowych do przepisów

${ }^{25}$ W. Warkałło, W sprawie teoretycznego charakteru studiów prawniczych, „Prawo” 1931, nr 5-6, s. 281.

${ }^{26}$ O. Balzer, Glosy do artykutu..., s. 52.

${ }^{27}$ K. Fleszyński, Szkoła prawa i szkoła życia, „Głos Sądownictwa” 1936, nr 9, s. 649-654.

${ }^{28}$ B. Winiarski, op. cit., s. 146.

${ }^{29}$ Według Stanisława Estreichera „dobrym prawnikiem praktycznym, a więc dobrym sędzią, adwokatem, urzędnikiem politycznym czy skarbowym, zwłaszcza gdy chodzi o stanowiska kierownicze, może być tylko ten, kto umie obejmować całość życia prawnego, a nie ten, kto zna tylko pewną ilość pozytywnych przepisów i pewną ilość biurowych sposobów załatwiania spraw". S. Estreicher, Nauczanie prawa publicznego na uniwersytetach polskich i reformy pożadane, Poznań 1936, s. 1.

${ }^{30}$ C. Martyniak, Pare uwag do dyskusji nad reforma studiów prawniczych, „Prąd” 1937, nr 4, s. 245.

${ }^{31}$ Ibidem. 
prawnych, ale jako humanista przygotowany w trakcie studiów do szerokiego i wszechstronnego spojrzenia na rzeczywistość społeczną ${ }^{32}$. Sprowadzenie wykonywania prawa do funkcji technicznej było czymś absolutnie niedopuszczalnym, gdyż prawo nie było jednostronną i jednowymiarową dziedziną życia, by można ją było porównywać z mechaniką czy farmacją, a roli prawnika - z rolą technika, tyle że działającego na odcinku społecznym ${ }^{33}$.

Przyjmując powyższe złożenie dotyczące celu studiów, zwolennicy humanistycznej perspektywy zdecydowanie odrzucali postulaty większego upraktycznienia nauczania prawa. Argumentowali, że okres studiów jest czasem formowania charakteru i nabywania umiejętności prawniczego myślenia ${ }^{34}$, natomiast nabyciu praktycznej znajomości przepisów prawnych służył okres aplikacji. Przekształcenie studiów uniwersyteckich w kierunku praktycznego nauczania byłoby niepotrzebnym dublowaniem aplikacji, a w tej sytuacji stawała się ona zbędna ${ }^{35}$. Dyplom uniwersytecki powinien gwarantować, iż absolwent opanował sztukę prawniczego myślenia, a nie że posiada duży zasób wiedzy na temat konkretnie obowiązujących przepisów prawa. Zadaniem uniwersytetu nie było wypuszczanie gotowych prawników, którzy już niczego nie musieliby się uczyć. Zresztą tak naprawdę poznawanie przepisów prawa rozpoczynało się dopiero po okresie studiów i trwało całe życie. Co więcej, wobec dużej zmienności obowiązujących norm prawnych nauczanie aktualnie obowiązujących przepisów byłoby bezsensowne, gdyż z każdą zmianą taki prawnik musiałby praktycznie wszystkiego uczyć się od początku. Absolwent prawa powinien zatem nie tyle znać treść obowiązujących przepisów, ile umieć je zastosować, rozumieć ich znaczenie oraz dostrzegać istotę konkretnych instytucji prawnych, wreszcie - umieć znaleźć rozwiązanie w każdej sytuacji.

Podkreślane było twierdzenie, że praktyk dobrze znający przepisy prawa, ale bez teoretycznej podstawy, miał umysł przywykły do rutyny, co powodowało, iż wykonywanie prawa przez niego stawało się schematyczne, nabierało charakteru rzemieślniczego ${ }^{36}$. Wyższość ogólnego prawniczego wykształcenia nad praktycznym - specjalistycznym - łatwo dawała się dostrzec w sytuacjach spraw nietypowych, nieszablonowych, niemieszczących się w pewnych przyjętych schematach. W takich sytuacjach prawnik wykształcony praktycznie byłby bezradny, natomiast teoretyk, przygotowany do abstrakcyjnego rozumowania i analizowania

${ }^{32}$ B. Winiarski, op. cit., s. 147.

${ }^{33}$ Ibidem, s. 157.

${ }^{34}$ K. Fleszyński, op. cit., s. 650.

${ }^{35}$ Por. z systemem nauczania w USA - studia mają praktyczny charakter, ale nie ma też okresu aplikacji przygotowującego do faktycznego wykonywania zawodu. Szerzej o systemie nauczania w USA zob. F. Zoll, Jaka szkoła prawa? Czy amerykańskie metody nauczania moga być przydatne w Polsce?, Warszawa 2004, s. 47-89; A. Rochowicz, Edukacja prawnicza w USA, „Palestra” 1994, nr 7-8.

${ }^{36}$ W. Warkałło, op. cit., s. 281. 
rozmaitych sytuacji, bez trudu znalazłby właściwe rozwiązanie zawiłej lub nietypowej sprawy ${ }^{37}$. Stosowanie prawa należało traktować jako pewien rodzaj artystycznego działania, opartego na błyskotliwości i nieszablonowości myślenia.

Ponadto, mocno akcentowano, iż tak naprawdę uniwersytet, jako instytucja o typowo akademickim charakterze, nie byłby w stanie nauczać praktycznego stosowania prawa. Właściwszym sposobem praktycznego nauczania prawa byłoby już raczej praktykowanie w kancelariach prawniczych ${ }^{38}$. Nauczanie na uniwersytecie, nawet jeśli byłoby skierowane w kierunku praktycznego przekazywania wiedzy, byłoby tak naprawdę pseudopraktyką i jedynie pewnego rodzaju imitowaniem rzeczywistego stosowania prawa. W takiej sytuacji zdecydowanie lepszym rozwiązaniem było nabywanie praktycznej wiedzy w trakcie odbywania praktyki pod okiem fachowca, niż w czasie zajęć na wydziale prawa ${ }^{39}$.

Z postulatem praktycznego nauczania prawa szedł jednocześnie postulat wprowadzenia specjalizacji na studiach prawniczych, która miała być odpowiedzią na znaczne skomplikowanie się rzeczywistości społecznej i powstanie nowych działów prawa. Zwolennicy humanistycznego ujęcia podkreślali, iż nie są przeciwnikami specjalizacji, która na pewnym etapie w karierze prawniczej była konieczna, lecz jedynie specjalizacji przedwczesnej ${ }^{40}$. Przede wszystkim wskazywano, że wprowadzanie jej na studiach wymusiłoby zbyt wczesne opowiedzenie się, jaki zawód chce się wykonywać, co rodziło niebezpieczeństwo, że w sytuacji niepowodzenia na konkretnej aplikacji przed absolwentami prawa automatycznie zmykały się drzwi do kariery prawniczej ${ }^{41}$. Zgodnie z tym stanowiskiem postulaty wczesnej specjalizacji, odbywanej już w trakcie studiów, były pochodną przyjęcia założeń, że prawo jest dziedziną podobną do zawodów technicznych oraz że studia mają przygotować do wykonywania z góry określonego zawodu ${ }^{42}$. Tymczasem trudno było ustalić, jakie konkretne zawody prawnicze będą występowały na rynku w przyszłości, stąd też za jakiś czas może się okazać, iż uczelnie nauczają zupełnie nieprzydatnych umiejętności ${ }^{43}$. Trudno

${ }^{37}$ B. Winiarski, op. cit., s. 146.

${ }^{38}$ Głos w dyskusji prof. Taylora w: Sprawozdanie z I Zjazdu Profesorów i Docentów Prawa Publicznego..., s. 31.

${ }^{39}$ Takie oskarżenia pojawiają się np. w Stanach Zjednoczonych wobec tzw. metody case study Christophera Columbusa Langdella, opartej na analizie orzecznictwa sądów apelacyjnych i mającej wdrożyć studentów prawa do „myślenia jak prawnik”. Wiele krytyków tej metody podkreśla, iż pomimo pewnego praktycznego elementu widocznego na pierwszy rzut oka, metoda ta ma charakter typowo akademicki i tak naprawdę uczy jedynie „myślenia jak profesor prawa”. Zob. M. Moskovitz, From case method to problem method: The evolution of a teacher, „Saint Louis University Law Journal” 2004, nr 48, s. 1214.

${ }^{40}$ Wywiad z profesorem dr. Antonim Peretiakowiczem..., s. 7; B. Winiarski, op. cit., s. 155.

${ }^{41}$ K. Fleszyński, op. cit., s. 651.

${ }^{42}$ B. Winiarski, op. cit., s. 159.

${ }^{43}$ Bardzo ciekawe prognozy dotyczące kierunku zmian charakteru zawodów prawniczych powiązanych ze zmianami społecznymi ostatnich dekad przedstawił Richard Susskind, według 
było zresztą jednoznacznie określić wyraźną granicę pomiędzy poszczególnymi zawodami prawniczymi, a zwłaszcza prognozować, w jakim kierunku będą się w przyszłości rozwijać.

Należało wreszcie pamiętać, iż po ukończeniu studiów prawniczych absolwent mógł pracować w wielu zawodach, niekoniecznie typowo prawniczych - być aktywnym w działalności społecznej czy dyplomatycznej ${ }^{44}$. Studia prawnicze nie determinowały konieczności wykonywania po ich ukończeniu z góry określonego zawodu, jak to miało miejsce po studiach inżynierskich. Podkreślano, że większość absolwentów prawa nie pracuje w zawodach prawniczych ${ }^{45}$. W takiej sytuacji o wiele bezpieczniejsze i lepsze, patrząc pod względem ścieżek kariery aktualnych studentów, było przekazywanie im wiedzy ogólnej, która mogła znaleźć zastosowanie na wielu płaszczyznach społecznych. Zbyt szybka specjalizacja przedwcześnie zamykała horyzonty myślowe przyszłych prawników i w konsekwencji zmniejszała realne możliwości zmiany wykony wanego zawodu ${ }^{46}$. Ponadto rzadko zdarzało się, by prawnikowi do rozwiązania jakiejś sprawy wystarczała wiedza wyłącznie z jednego działu prawa, lecz zwykle musiał on stosować różne przepisy z wielu dziedzin prawa ${ }^{47}$. Zatem zbytnia specjalizacja znacząco utrudniłaby prawidłowe wykonywanie zawodu prawniczego.

Odmiennie argumentowali zwolennicy technicystycznego ujęcia nauki uniwersyteckiej, podkreślający nieadekwatność dotychczasowych rozwiązań w edukacji prawniczej do aktualnych wymogów rzeczywistości społecznej. Negowali oni wizję uczelni jako instytucji zajmującej się nauką dla samej nauki, bez odniesienia do jej społecznej roli. Uniwersytety oskarżane były o to, że jako „dostojne świątynie wiedzy”48 żyły w kompletnym oderwaniu od rzeczywistości, będąc rodzajem „izolowanych twierdz” albo „muzeum średniowiecznych środków dydaktycznych”49. Większość profesury była posądzana o nadmierny konserwatyzm, zaślepienie i uleganie złudzeniom, jakoby profesja prawnicza miała charakter humanistyczny.

którego następuje zmierzch klasycznie rozumianych zawodów prawniczych. Zob. R. Susskind, Tomorrow's Lawyers. An Introduction to Your Future, Oxford 2013, s. 3 i n.

${ }^{44}$ B. Winiarski, op. cit., s. 159.

${ }^{45}$ Obecnie na uczelnie na podstawie ustawy z dnia 27 lipca 2005 r. - Prawo o szkolnictwie wyższym, Dz. U. 2005, nr 164, poz. 1365 z późn. zm., został nałożony obowiązek śledzenia dalszych losów absolwentów, co w przyszłości da przynajmniej częściową odpowiedź na pytanie, jak wielu absolwentów studiów prawniczych wykonuje zawód typowo prawniczy. Wcześniej takie badania były już przeprowadzane w sposób fragmentaryczny. Zob. Z. Rogoziński, Absolwenci Wydziału Prawa UW. Wstępne wyniki badań ankietowych, „Państwo i Prawo” 1969, z. 10, s. 377-387.

46 Wywiad z profesorem dr. Antonim Peretiakowiczem..., s. 7.

${ }^{47}$ K. Fleszyński, op. cit., s. 651.

${ }^{48}$ H. Wąsowski, O reformę studiów prawniczych, „Współczesna Myśl Prawnicza” 1936, nr 5, s. 16.

${ }^{49}$ K. Fleszyński, op. cit., s. 649. 
Według stanowiska technicystycznego prawnik nie był humanistą, lecz wykonywał na gruncie społecznym podobną rolę, jak inżynier w budownictwie czy lekarz w leczeniu pacjentów ${ }^{50}$. Podkreślano, że, co prawda, wykonywanie części zawodów prawniczych miało charakter twórczego i kierowniczego oddziaływania na społeczeństwo, i wtedy można mówić o prawniku jako o inżynierze społecznym ${ }^{51}$. Natomiast większość profesji prawniczych miała charakter typowo wykonawczy, a osoby takie można nazwać technikami społecznymi. O ile inżynierowie społeczni powinni posiadać szeroką wiedzę dotyczącą procesów społecznych, umożliwiającą ich stymulowanie i ukierunkowywanie, to technikom społecznym w zupełności wystarczyła prosta znajomość obowiązujących przepisów. Zwolennicy technicystycznego ujęcia zawodów prawniczych podkreślali, iż metodologia pracy prawnika ma charakter typowo ścisły, dlatego też błędne jest kształcenie prawników w kierunku humanistycznym.

Skutkiem dotychczasowego - humanistycznego - sposobu kształcenia było to, iż mury uczelni co roku opuszczały gromady absolwentów kompletnie nieprzystosowanych do pracy w zawodzie, posiadający ,niewątpliwą łatwość wymowy, czy gadaniny, [...] polot towarzyski i przyrodzoną zdolność do tańca" ${ }^{52}$, lecz w ogóle nieznający, albo znający bardzo wybiórczo, przepisy obowiązującego prawa. Prowadziło to do sytuacji, że uczelnie właściwie nie przygotowywały prawników do pełnienia ich społecznych ról, na masową skalę produkując rzeszę prawniczych dyletantów ${ }^{53}$. Na studiach nauczano ich przede wszystkim przedmiotów, które dawno już straciły swoje znaczenie albo w żaden sposób nieprzydatnych w późniejszej praktyce zawodowej. Mocno podkreślano, że okres studiów uniwersyteckich to czas, kiedy nauczani są praktycy potrzebni społeczeństwu, którzy powinni otrzymać solidne przygotowanie do wykonywania przyszłego zawodu ${ }^{54}$. Aby tego dokonać, prawnik nie mógł mieć umysłu zasklepionego w teoretycznych formułach, lecz powinien być nastawiony na rozwiązywanie realnych problemów. Prawnik posiadający wiedzę teoretyczną uzyskaną wyłącznie na podstawie książek, bez jej zweryfikowania w realnym życiu, był jednostką mało pożyteczną społecznie ${ }^{55}$. Do wykonywania swojego przyszłego zawodu, polegającego na przebudowywaniu struktury społecznej i kierowaniu procesami

${ }^{50}$ J. Ordoniec, Dyletantyzm czy specjalizacja?, „Współczesna Myśl Prawnicza” 1937, nr 1, s. 12.

${ }^{51}$ Zagadnienie reformy uniwersyteckich studiów prawniczych, Związek Zrzeszeń Młodych Prawników RP, Warszawa 1936, s. 8.

${ }^{52}$ C. Znamierowski, Młodzież prawnicza II, „Gazeta Polska”, 27 sierpnia 1937, s. 3.

53 J. Dominikówna, Przed reformq uniwersyteckiego studium prawa w Polsce, „Prawo” 1936, nr 5-6, s. 177.

${ }^{54}$ Zob. C. Znamierowski, Młodzież prawnicza II, s. 3; J. Bekerman, Nieco o studiach prawniczych, „Głos Sądownictwa” 1937, nr 4, s. 314.

${ }^{55}$ H. Wąsowski, op. cit., s. 16. 
społecznymi, nie mógł być dyletancko przygotowany - bowiem nie mając odpowiedniej wiedzy lub umiejętności praktycznych, byłby znachorem, a nie inżynierem społecznym ${ }^{56}$.

Ponadto uzasadnieniem dla praktycznego sposobu nauczania miały być aktualne potrzeby społeczne. Społeczeństwo ponosiło koszty studiów uniwersyteckich, w zamian otrzymując absolwentów słabo przygotowanych do wykonywania zawodu, przez co nakłady ponoszone na naukę były właściwie w znacznym stopniu marnowane ${ }^{57}$. W dotychczasowym, teoretycznym modelu nauczania kształciło się wszystkich studentów w jednakowy sposób, właściwy dla kształtowania umysłu naukowca - teoretyka. Z ogółu studentów tylko nieliczne osoby decydowały się na kontynuowanie kariery naukowej, gdy tymczasem miażdżąca większość absolwentów prawa wykonywała zawody praktyczne. W ten sposób powstawała sytuacja, że uczelnie tak naprawdę kształciły ewentualnych naukowców, gdy tymczasem społeczeństwo potrzebowało przede wszystkim praktyków ${ }^{58}$. Studia powinny być zorientowane głównie na kształcenie praktyczne, co miało się odbywać w zasadzie bez szkody dla wyłaniania przyszłych naukowców, gdyż - jak argumentowano - ci zazwyczaj swój sukces zawdzięczali nie teoretycznemu sposobowi nauczania, ale własnej pracy i samozaparciu ${ }^{59}$. W zmianie sposobu nauczania miał się realizować postulat, by uczelnie funkcjonowały dla społeczeństwa, odpowiadając na jego potrzeby, a nie istniały jako „wieże z kości słoniowej” - instytucje kompletnie oderwane od realiów, funkcjonujące same dla siebie ${ }^{60}$.

Na zarzuty zwolenników perspektywy humanistycznej, iż praktyczne nauczanie spowoduje przemianę uniwersytetów w szkoły prawa, na masową skalę produkujące niedouków, Juliusz Makarewicz odpowiadał, że można wyróżnić dwa rodzaje niedouków. Pierwszy rodzaj niedouka to człowiek, który ma dużą wiedzę jedynie $\mathrm{w}$ wąskiej specjalistycznej dziedzinie, a w innych dziedzinach bardzo małą, a z kolei drugi typ - to osoba, która posiada powierzchowną wiedze z wielu dziedzin ${ }^{61}$. Pierwszy typ niedouka miał być efektem kształcenia praktycznego, natomiast drugi - kształcenia ogólnego. Zwolennicy technicystycznej perspektywy nauczania prawa argumentowali, iż dla społeczeństwa mniej

${ }^{56}$ C. Znamierowski, Zagadnienie reformy uniwersyteckich studiów prawniczych, „Współczesna Myśl Prawnicza” 1936, nr 8-9, s. 23.

${ }^{57}$ Z. Sitnicki, O reformę studiów prawniczych, „Głos Sądownictwa” 1934, nr 5, s. 263.

${ }^{58}$ C. Znamierowski, Zjazd profesorów prawa, „Gazeta Polska”, 5 maja 1936, s. 9; H. Wąsowski, op. cit., s. 16.

59 „Dla naukowców jako takich nie trzeba obowiązkowych masowych wykładów, ani też z góry dla wszystkich układanych programów. Bo wielkości się nie stwarza i nie kształtuje według jednego dla wszystkich wzoru, lecz ona sama się rodzi” - H. Wąsowski, op. cit., s. 17.

${ }^{60}$ Głos w dyskusji prof. Znamierowskiego w: Sprawozdanie z I Zjazdu Profesorów i Docentów Prawa Publicznego..., s. 22; J. Makarewicz, Reforma metody nauczania ..., s. 119.

${ }^{61}$ J. Makarewicz, Reforma metody nauczania..., z. 1-3, s. 11. 
przydatny jest drugi typ niedouka, gdyż nie przedstawiał on zbyt wielkiej wartości na rynku pracy. Absolwenci posiadający wyłącznie pewną fragmentaryczną wiedzę teoretyczną nie byli chętnie zatrudniani przez pracodawców, gdyż nie posiadali praktycznych umiejętności i wiedzy, potrzebnych na rynku pracy.

Wszystkie te argumenty miały przemawiać za koniecznością praktycznego kształcenia prawników. Chętnie powoływano się w tym zakresie na Anzelma Furebacha, który pisał:

Prawo ludu rzymskiego dojrzewało nie pod wpływem historii, archeologii, krytyki i gramatyki, jako nauka historyczna, lecz pod wpływem doświadczenia. Rzymski uczony prawnik nie siedział jako badacz historii i starożytności nad pamiątkami i rękopisami, lecz na rynku albo w domu z klientami, albo na krześle sędziowskim. Jego nauka była wiedzą zaczerpniętą z życia codziennego, mało czytał i uczył się, za to więcej obserwował i myślał, zastanawiał się, wyprowadzał wnioski ${ }^{62}$.

Wreszcie wskazywano na wybitnie praktyczny charakter wykonywania zawodu prawniczego, którego nie można było się nauczyć tylko i wyłącznie czytając książki i słuchając wykładów ${ }^{63}$. Sędzia Józef Bekerman porównywał teoretyczne nauczanie prawa do nauczania muzyki w konwersatorium, gdzie uczono by tylko i wyłącznie suchej ogólnej wiedzy z teorii i historii muzyki, a wcale nie uczono grać na jakimkolwiek instrumencie ${ }^{64}$. Podobny charakter miało mieć nauczanie prawa bez odniesienia nabywanej wiedzy do praktyki.

W parze w koniecznością zmiany modelu nauczania prawa szły postulaty większej specjalizacji już w okresie nauczania akademickiego. Podstawowym argumentem, jaki przytaczano, było stwierdzenie o szybkim rozrastaniu się zakresu obowiązującego prawa, którego nikt nie jest w stanie się nauczyć w okresie studiów $^{65}$. Model nauczania wymagający dobrego opanowania każdej dziedziny prawa był anachronizmem nieodpowiadającym aktualnym potrzebom rzeczywistości. Współcześnie podkreśla się konieczność specjalizacji, spowodowaną postępującymi procesami globalizacji oraz zalewem prawodawstwa europejskiego ${ }^{66}$. W sytuacji ogromnej liczby przepisów obowiązującego prawa specjalizacja

${ }^{62}$ Cyt. za: J. Warlewski, Problematyka modelu edukacji prawniczej w Polsce, „Edukacja Prawnicza” 2006, nr 6, s. 34.

${ }^{63}$ Sędzia Bekerman twierdził, że ,prawnik zaczyna myśleć jako taki, gdy schodzi z wyżyn abstrakcji i przechodzi na grunt rzeczywistości - czego żaden wykład ex cathedra zastapić nie może”. J. Bekerman, O reformie studiów prawniczych, „Palestra” 1934, nr 9, s. 566.

${ }^{64}$ J. Bekerman, Nieco o studiach prawniczych, „Głos Sądownictwa” 1937, nr 4, s. 314.

${ }^{65}$ Z. Sitnicki, op. cit., s. 361.

${ }^{66}$ Zob. F. Zoll, Przyszłość kształcenia prawników w Polsce, „Państwo i Prawo” 2010, z. 6, s. 24-26; A. Radwan, Uniwersytecka edukacja prawnicza w dobie globalizacji, „Państwo i Prawo" 2004, nr 11. Z problemem globalizacji łączy się kwestia ujednolicania sposobów nauczania na studiach prawniczych - zob. A. Korybski, O standaryzacji nauczania na studiach prawniczych, „Państwo i Prawo” 2004, nr 2; J. Borkowski, Standaryzacja nauczania w naukach prawnych, „Państwo i Prawo” 2004, nr 2. 
jest jedyną możliwością, by prawnik w profesjonalny sposób wykonywał swoją rolę inżyniera bądź technika społecznego. Wymagać od prawnika, by był specjalistą i posiadał szczegółową wiedzę z każdej dziedziny prawa, to jakby wymagać od inżyniera, by był specjalistą z każdej dziedziny mechaniki. Stawianie takich wymogów prowadziło nie do profesjonalizmu, lecz zwykłego dyletantyzmu.

Wreszcie argumentem potwierdzającym konieczność specjalizacji był fakt komplikowania się rozmaitych relacji społecznych, za którymi szły szczegółowe regulacje prawne. W tej sytuacji prawnik, aby dobrze wykonywać swoją społeczną rolę, musiał się do tego procesu dostosować. Dodatkowo, należy pamiętać, że zawody prawnicze nie maja jednolitego charakteru, lecz - przeciwnie - wykonywanie każdego z nich wymaga zupełnie innych umiejętności i zupełnie innej wiedzy ${ }^{67}$. Z tego względu trudno sobie wyobrazić, by możliwe było kształcenie w jednakowy sposób przyszłych sędziów, adwokatów czy prokuratorów. Argumentowano, że przecież nikt w taki sam sposób nie kształci inżynierów zajmujących się budową mostów i budową maszyn ${ }^{68}$.

Zarysowany powyżej spór pomiędzy zwolennikami teoretycznego i praktycznego sposobu nauczania prawa wpisuje się w dyskurs pomiędzy humanistyczną a technicystyczną perspektywą roli nauki i nauczania. Zwolennicy humanistycznego charakteru studiów dążą do tego, by uniwersytety opuszczały osoby świadome swojej przyszłej roli w społeczeństwie - bycia strażnikami praworządności i sprawiedliwości, a przede wszystkim posiadające wiedzę o tym, jakie obowiązki wiążą się z pełnieniem takiej roli. Podkreślane jest tu przede wszystkim znaczenie oddziaływania wychowawczego na społeczeństwo, jakie zachodzi przy stosowaniu przepisów prawa, którego w żaden sposób nie można bezpośrednio przełożyć na wymierne efekty. Zatem aby prawnik mógł w prawidłowy sposób pełnić swoją społeczną funkcję, w trakcie studiów należało przede wszystkim wykształcić jego osobowość. Większy nacisk trzeba było położyć na kształtowanie charakteru i kręgosłupa moralnego przyszłego prawnika, niż na znajomość konkretnych przepisów prawa.

Zupełnie przeciwne zapatrywanie na rolę prawnika w społeczeństwie oraz na etap przygotowania go do jej pełnienia mają zwolennicy ujęcia technicystycznego. Zgodnie z ich wizją prawnik jest profesjonalistą zajmującym się rozwiązywaniem konkretnych problemów prawnych, stąd też potrzeba mu fachowej i szczegółowej wiedzy, by móc tę rolę realizować. W tym ujęciu bardziej liczyły się wymierne efekty pracy prawnika, niż długofalowe oddziaływanie na społeczeństwo. Nie znaczy to, że aspekt społecznej roli prawnika był pomijany, lecz przedstawiano go bardziej jako pewnego rodzaju profesjonalnego społecznego menedżera, albo - jak pisano w okresie międzywojennym - inżyniera

${ }^{67}$ C. Znamierowski, Zagadnienie reformy..., s. 23.

${ }^{68}$ Józef Ordoniec podkreślał: „Nie zanotowano jeszcze wypadku, aby ktoś skończył wszystkie działy politechniki nawet w ciągu lat 5" - J. Ordoniec, op. cit., s. 9. 
społecznego. Do pełnienia takiej roli potrzebne były określone umiejętności i dobra znajomość przepisów prawa, a wymierne efekty pracy prawników miały być od razu widoczne. Technicystyczna wizja pracy prawnika stawia zatem raczej na skuteczność działania i uzyskiwanie efektów w określonym czasie, co nie oznacza deprecjonowania zasad etyki, jednakże nie one stanowią istotę wykonywania tego zawodu.

Nakreślony w niniejszym tekście spór o charakter studiów prawniczych ma swoje źródło w dwóch przeciwstawnych sobie wizjach prawnika i jego roli społecznej. Tendencje te są nie do pogodzenia, gdyż opierają się na zupełnie odmiennych wizjach istoty prawa oraz sposobu jego wykonywania. Wizja pierwsza podkreśla przede wszystkim humanistyczny wymiar pracy prawnika i wymaga od niego, by w swojej pracy kierował się przede wszystkim pewnymi wartościami, a dopiero w dalszej kolejności efektami pracy. Z kolei druga wizja każe prawnikowi być przede wszystkim profesjonalnie przygotowanym fachowcem w swojej dziedzinie, skutecznie świadczącym pomoc prawną, a samo wykonywanie zawodu postrzegane jest bardziej w sposób techniczny. Z powodu przeciwstawności tych dwóch ujęć modelu nauczania prawa należy wątpić, czy spór o charakter zawodu prawniczego kiedykolwiek zakończy się kompromisem. Również wątpliwe wydaje się ostateczne zwycięstwo którejkolwiek ze stron tego konfliktu. Należy raczej sądzić, że w bliższej czy dalszej przyszłości dyskusja o humanistycznym czy technicystycznym charakterze pracy prawnika, a także sposobie jego edukacji, toczyć się będzie nadal. 